\title{
The Entreprenurial Perception of SME Business Environment Quality in the Czech Republic
}

- Kljućnikov Aleksandr, Belás Jaroslav, Kozubíková Ludmila, Paseková Pavla

\begin{abstract}
This article defines and quantifies important factors of the quality of the business environment for small and medium-sized firms (SMEs) in the Czech Republic.To do so, itcompares the attitudes of entrepreneurs categorized by gender, education, age and firm size. A study of the business environment was conducted in 2015 from a sample of 1,141 respondents (the owners of companies), and the results were analyzed. It was found that only $10 \%$ of the entrepreneurs positively evaluated the applicable forms of state financial support. The study also demonstrated no statistically-significant response differences among the designated social groups. 64\% of Czech entrepreneurs feel the support of their surroundings while doing business, $45 \%$ think that SMEs have restricted access to external sources of financing, and over half note the intensive influence of market risk. It was also determined that there are statistically-significant differences in the pattern of responses between men and women and between micro-enterprises and small and medium-sized enterprises.
\end{abstract}

Keywords: small and medium-sized enterprises, business environment quality, state financial support, credit risk, market risk, Czech Republic

JEL Classification: L26, O16, G32

\section{INTRODUCTION}

Small and medium-sized enterprises (SMEs) represent an important part of the economic system, due to their significant positive impact on such macroeconomic indicators of the country as gross domestic product, employment, added value and revenue of the state budget.

SMEs play an important role in the economic system of the Czech Republic. The share of small and medium-sized enterprises on the total number of active business entities in the Czech Republic in 2013 was $99.83 \%$, while the share in value added was $55 \%$. Share of SMEs' employees in total employment in business sector in the Czech Republic in 2013 was 60 \%. (MPO, 2014)

In this context, the quality of the business environment for SMEs is an important precondition for the successful development of this business segment.

In this article we evaluate the major determinants of the quality of the business environment in the segment of SMEs, such as the system of financial support from the State, the impact of the surrounding on business environment, SMEs access to external financing sources and the perception of market risk in the sector. These important aspects of the quality of the business environment are evaluated in terms of defined social groups. 


\section{THEORETICAL BACKROUND}

The issue of the quality of the business environment for SMEs is a very actual area of scientific research.

SMEs have several specific properties that relate to their limited size, a lower degree of diversification, low capital strength, more limited market and a higher risk. On the other hand, however, they are more flexible because they can rapidly adapt to new needs, have closer contact with customers and are of great importance for employment in the economy. (Fetisovová et al., 2012)

SMEs, unlike large enterprises are confronted with competitive disadvantages in the field of finance, manufacture, human resources, legal and strategic area (Pavelková et al., 2009) resulting from the nature of small and medium-sized business (Májková, 2012).

SMEs access to financial resources and the possibility to obtain financial resources determines the quality of the business environment in a significant way. In this context, several authors define the term financial gap for SMEs. (Fetisovová et al., 2012, Májková, 2012). According to Fetisovová et al. (2012) the financial gap is a situation where a significant part of SMEs is no table to fulfill its financial needs. In this context, the author defines risk of financing as the possibility that the company will not be able to implement its strategic intentions due to financial reasons. This risk may manifest itself as an inability to obtain the required amount of funds at a given time, whether by the concentration of equity, by obtaining credit resources or due to the enormous price growth of these resources.

The issue of small and medium enterprises financing is one of the key themes of the European Union in recent years. The aftermath of the financial crisis and subsequent economic recession still persist in some Member States and European institutions are still looking for ways to facilitate the access of SMEs to finance and to offer them the new ways of funding that would be an alternative to traditional bank loans. (MPO, 2014)

The government of the Czech Republic evaluates the support of SMEs through regular annual reports. The report on the state of small and medium enterprises in the Czech Republic for 2013 states that since the beginning of implementation till the 31.12.2013 through the subsidy programs of the Operational Program Enterprise and Innovation the total amount of 36,236.4 mil. CZK was provided and used exclusively for SMEs. The total number of 8,739 firms gained this amount of funding from the period of 2007 to 2013. In 2013 through the program TIP the Ministry of Industry and Trade supported 235 projects of small and medium-sized enterprises by the total amount of 870 mil. CZK. The Ministry of Education, Youth and Sports in 2013 as a part of the EUREKA program provided SMEs with 88.424 mil. CZK and with the amount of 3,662 mil. CZK on supporting international projects from the targeted support of the program KONTAKT II. Ministry of Regional Development in 2013 allocated through the National Tourism Support Program the funding of 31 projects for SMEs in total of 50,1 mil. CZK. The Ministry of Agriculture implemented the Rural Development Program of the Czech Republic, under which reimbursed 324 projects of small and medium-sized enterprises the total amount of approximately 1,344 billion CZK in 2013. (MPO, 2014)

The quality of the business environment is significantly determined by a variety of social factors, such as, for example societal perceptions of entrepreneurs, the quality of the education system 
in the context of business activities, cultural aspects, and also the relationship of the closest surrounding to the business activities of the individual.

Analysis of business activities within the international project Global Entrepreneurship Monitor (GEM) reports that the image of entrepreneurs is still very poor - less than half of our population does not perceive that successful entrepreneurs have high status. It is necessary to work on creating positive role models. Experts state that the field of the cultural and social norms remains to be problematic. Our culture does not support both the adoption of business risks and the success achieved by our own efforts nor self-sufficiency and independence. Entrepreneurship education, especially in primary and secondary schools, is seen as one of the weakest areas. Experts recommend fundamental changes in the education system and the incorporation of entrepreneurship education as its integral part. It is necessary to include support for creativity, initiative, self-confidence and willingness to take risks already in the early stages of the education system. (MPO, 2014)

A significant disadvantage of SMEs is the restricted access to external financing (bank loans and other forms of external financing), which is caused by high risk level of these firms, because they are generally characterized by a high degree of indebtedness and limited capability to provide the guarantee for their commitments. Due to this fact the obtaining of commercial loans is problematic for these businesses. That is why they acquire loans under less favorable conditions, even assuming that their business plan is viable and profitable (Májková, 2012). The similar view is also presented by other authors, for instance Ozturk and Mrkaic (2014), Kundin and Erecgovac (2011), Fetisovová et al. (2012).

In this context we present the evaluation of the Ministry of Industry and Trade of the Czech Republic. In general we can state that Czech SMEs did not have substantial problems with the access to bank financing. Therefore the greater support of alternative (i.e. non-bank) funding sources in the Czech Republic would probably have had virtually no significant impact, due to the fact that most of the companies had not planned major investments and had been waiting for the further situation development. Czech banking sector has sufficient resources in the form of primary deposits (the ratio of deposits to loans amounted at the end of 2013 level of $146.4 \%$ ) and the SME segment for 45 banks operating on the Czech highly competitive market is still attractive. (MPO, 2014)

The quality of the business environment for SMEs is in significant manner determined by the existence of business risks. The companies are being influenced by the variety of risks, the most important of which is the primary market risk.

Market risk is determined by the objective development of the market in a given sector. The market decides whether the company succeeds in an effective way to sell its products, and how the prices of inputs will develop. In particular company this risk also encompasses mistakes in the strategic management, investments, loss of customers, and the pressure of competition. (Fetisovová et al., 2012)

It is obvious that if the enterprise is exposed to intense influence of market risk, the foundations and the meaning of enterprises existence is endangered. 
In the current period of time the intensive influence of market risk can be presumed. Financial and economic crisis had serious implications for the performance of SMEs in the European Union. According to estimates, the gross production in these companies decreased by $5.5 \%$ in 2009 , and the insufficient demand with the purchasing power represented the most urgent problem for $29 \%$ of SMEs, while the demand development forecasts were pessimistic. (Fetisovová et al., 2012)

In 2013 we conducted a survey of the business environment in the Zlín region and in selected regions of Slovakia. Results of the research showed, that the most important business risks which were perceived by entrepreneurs in the Czech Republic and Slovakia were as follows: market, financial and personnel risks. Market risk was identified as a key risk by the largest number of entrepreneurs, which means $79.44 \%$ of them in the Czech Republic and $80.49 \%$ in Slovakia. (Belás, Macháček, Bartoš, Hlawiczka and Hudáková, 2014).

The report on the development of small and medium enterprises and their support in 2013 states, that the biggest problems in business are for the total amount of entrepreneurially active individuals associated with an insufficient amount of orders $(22 \%$ entrepreneurially active individuals) and in related to this fact strong competition (15\%). This perceived problem may indicate the imperfection of the business model of a group of entrepreneurially active individuals, where we can more or less probably identify the lack of focus on specific customer segments and offering of specific added value aimed at the needs and problems that this segment is also willing to pay for. (MPO, 2014)

The business environment is determined by a variety of factors such as gender, education, size and age of the company.

Examining of identical and different features between men and women belongs to the important area addressed by the multiple authors. Studies show that there are a lot of differences between men and women entrepreneurs. Goktan and Gupta (2015) state that individual entrepreneurial orientation is higher among men rather than women. They find that men are much more innovative, risk taking incentives and proactive in entrepreneurship development. Langowitz and Minniti (2007) found out that women are more risk averse than men. This finding confirm DiazGarcia and Jimenez-Moreno (2010) and at the same time they state that females are more innovative and objective in achieving task and men are likely to have a thought about the intention to create a firm rather than doing it in practically. Also Runyan et al. (2006) found out that females are more innovative than their male counterparts, but on the other hand in risk taking females scored more than the males and there were no significant differences found in proactivity.

Women have more communal qualities (expressiveness, connectedness, relatedness, kindness, supportiveness, timidness), while men are associated with more agentic qualities (independence, aggressiveness, autonomy, instrumentality, courage). (Gupta et al., 2009)

Some authors found out that, higher entrepreneurs' education can positively affect the performance of the firm and which also gives the company a more sustainable position in the market (Millian et al., 2014, Rauch and Rijsdik 2013), can easily find the different sources of financing (Kato et al., 2015), and can manage better the firm-specific financial risks. (Wang, 2012). 
Company's size and age can play an important role in the context of obtaining external sources of finance (Pervan and Kuvek, 2013, Canton, Grilo, Monteagudo, and Zwan, 2013). Increasing bank funding costs after crisis are associated with higher interest rates for the SMEs but not for the large firms. (Ozturk and Mrkaic, 2014) Non-financial information such as firm size is negatively related to failure and the age of the firm is quite confusing. The results show that, the firms aged within 3-9 years are more vulnerable to failure. (Altman, Sabato, and Wilson, 2010) On the other side for instance Situm (2014) states that age of the firm cannot be good bankruptcy predictor for the companies, and firm size is not statically different for the failed and non-failed firms.

\section{RESEARCH OBJECTIVE, METHODOLOGY AND DATA}

Aim of the article is to define and compare important determinants of the quality of the business environment of small and medium enterprises (SMEs) in the Czech Republic defined in terms of social groups. Within the stated objective we compare the evaluation of significant attributes of the quality of the business environment of men and women, entrepreneurs with higher education of with a different kind of education, micro enterprises and other SMEs, SMEs doing business for over 10 years and younger companies in the segment of SMEs.

The research of fundamental determinants of the quality of the business environment of SMEs has been conducted in 2015 through questionnaire survey in the Czech Republic. Data was obtained from 1.141 SMEs in the Czech Republic and provided by their owners. We gained the biggest amount of respondents in the Zlín Region (323), followed by the Moravian-Silesian Region with the total number of 276 respondents, the Olomouc region with 134 respondents, the South Moravian Region with 116 respondents, the Liberec Region with 58 respondents, the capital city of Prague with its 58 respondents, the Pardubice Region with 55 respondents, 31 respondents from the Plzeň Region, the Central Bohemian Region with 25 respondents, the Hradec Králové Region with 23 respondents, the Vysočina Region with 18 respondents, the South Bohemia Region with 11 respondents, the Ústecký Region with 10 respondents and the Karlovy Vary Region with only 3 respondents.

The questionnaire contains 52 questions. In the introductory part of the questionnaire we investigated the place, area and field of business, the length of doing business, the size of business, and the level education of the business owners, their gender, age, and motives for starting a business. In the next part of the questionnaire we investigated the attitudes of entrepreneurs in the specific areas which determine the quality of the business environment. In this part of the questionnaire we set the range of possible answers from 1 to 5 (1 - strongly agrees, 2 - agree, 3 - no stance to the problem, 4 - disagree, 5 - fully disagree).

The method of choosing companies was as follows. From the Albertina database using the random selection method, we chose the total of 1650 companies. These firms we contacted via email and their owners were asked to complete a questionnaire, which was placed on the website: https://docs.google.com/forms/d/1U9coaC5JRL0N2QOOO6Xb8j3mnaZXdSM47Ku gt4EDGFo/viewform? usp=send_form. In case that the company did not respond to our mail, it was contacted by telephone. 
The research was conducted on the base of the own structural model, which is shown in the Figure 1.

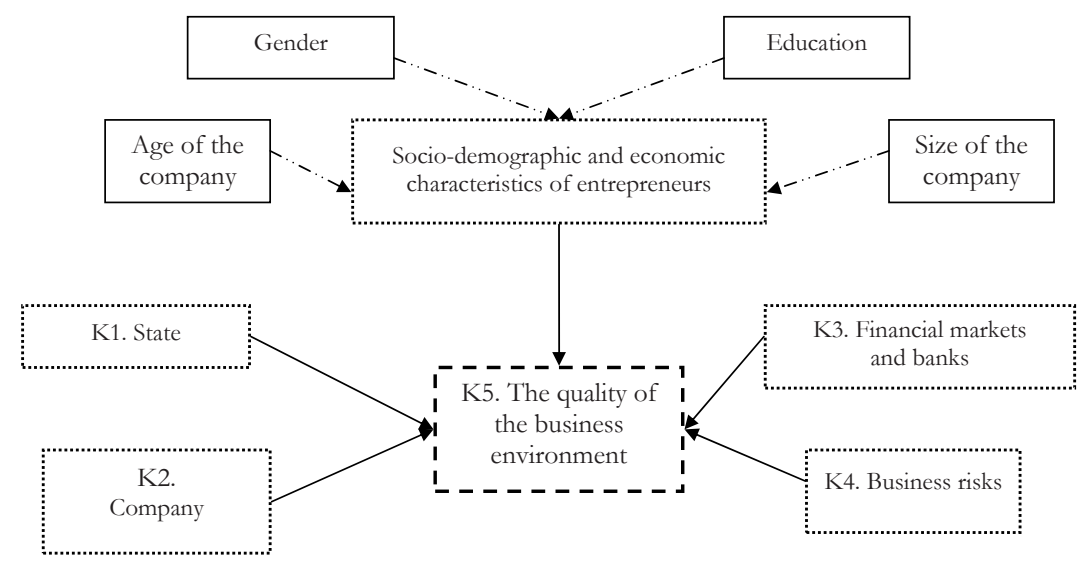

Fig. 1 - The structural model in the field of the quality of the business environment and the credit risk of SME.

\section{Source: own source}

In relation to the gender of the entrepreneur from total number of 1.141 owners of the companies $75 \%$ of them were men and $25 \%$ of them were women.

Most of the entrepreneurs in the sample, concretely $48 \%$ had secondary education, $34 \%$ of them had higher education and $18 \%$ had a secondary education without GCSE.

From the total number of surveyed firms $65 \%$ were micro enterprises, $27 \%$ were small enterprises and $8 \%$ were medium-sized enterprises. The size of the company was defined by the number of employees, where micro companies had up to 10 employees, small businesses up to 50 employees, medium-sized enterprises up to 250 employees.

In accordance to the length of doing business from the total number of companies $62 \%$ of them were doing business for more than 10 years, 21\% of them between 1 and 5 years, and 17\% of them between 5 and 10 years. It can be said that the owners of the companies were quite experienced entrepreneurs.

The structure of the sample according to the business area was as follows: trade companies $(33 \%)$, manufacturing companies $(23 \%)$, construction companies (14\%), transport companies $(6 \%)$ and agricultural firms $(3 \%)$. The largest portion of companies operated in other sectors $(39 \%)$.

In this research, following four hypotheses through estimation methods has been set:

H1. Not more than $20 \%$ of entrepreneurs positively evaluate the forms of state financial support.

There are no statistically significant differences between the designated social groups (men and women, entrepreneurs with higher education and others, and micro-enterprises and other enterprises, enterprises that operate over 10 years and others). 
H2. Not more than $50 \%$ of entrepreneurs feel the support of their surroundings for entrepreneurship. There are statistically significant differences between the designated social groups (men and women, entrepreneurs with higher education and others, and micro-enterprises and other enterprises, enterprises that operate in the market for over 10 years and others).

H3. More than $40 \%$ of entrepreneurs think that SMEs have the restricted access to external sources of financing (financial markets, banks, loans from the State). There are no statistically significant differences between the designated social groups (men and women, entrepreneurs with higher education and others, and micro-enterprises and other enterprises, enterprises that operate in the market for over 10 years and others) do not exist.

H4. At least $50 \%$ of entrepreneurs feel the intensive influence of market risk (lack of orders). There are statistically significant differences between the designated social groups (men and women, entrepreneurs with higher education and others, and micro-enterprises and other enterprises, enterprises that operate in the market for over 10 years and others).

While evaluating the various hypotheses we use the respondent's answer to selected questions from each construct $\mathrm{K} 1$ to $\mathrm{K} 4$.

Statistically significant differences between the designated social groups were compared through Pearson statistics at significance level of $5 \%$. If the calculated p-value was less than $5 \%$, we rejected the null hypothesis and the alternative hypothesis was adopted. The calculations were made using the free software, which is available at: http://www.socscistatistics.com/tests. Statistically significant differences in individual responses we investigated by the Z-score. The calculations were made using the free software, which is available at: http://www.socscistatistics. com/tests/ztest/Default2.aspx.

\section{RESULTS AND DISCUSSION}

Table 1 shows the results of the evaluation of the state financial support in terms of small and medium enterprises.

Tab. 1 - The evaluation of the state financial support in the Czech Republic. Source: own source

\begin{tabular}{|c|c|c|c|c|c|c|c|c|c|}
\hline \multicolumn{10}{|c|}{ The applied forms of state financial support are suitably adjusted. } \\
\hline & Men & $\begin{array}{l}\text { Wom- } \\
\text { en }\end{array}$ & $\mathrm{HE}$ & OE & Micro & OEn & $10+$ & $10-$ & $\begin{array}{l}\mathrm{p} \text {-value } \\
\mathrm{Z} \text {-score }\end{array}$ \\
\hline 1. strongly agree & 1 & 1 & - & 2 & 1 & 1 & 1 & 1 & \\
\hline $\begin{array}{l}\text { 2. agree } \\
\text { share in } \%(1+2) \\
\text { share in } \% \\
\text { total: } 9.55\end{array}$ & $\begin{array}{c}79 \\
9.29\end{array}$ & $\begin{array}{c}28 \\
10.36\end{array}$ & $\begin{array}{c}47 \\
11.99\end{array}$ & $\begin{array}{c}60 \\
8.28\end{array}$ & $\begin{array}{c}64 \\
8.78\end{array}$ & $\begin{array}{c}43 \\
10.97\end{array}$ & $\begin{array}{c}61 \\
8.79\end{array}$ & $\begin{array}{c}46 \\
10.78\end{array}$ & $\begin{array}{l}0.2713 \\
0.0424 \\
0.2301 \\
0.2670\end{array}$ \\
\hline $\begin{array}{l}\text { 3. no stance to } \\
\text { the problem }\end{array}$ & 273 & 85 & 126 & 232 & 240 & 118 & 202 & 156 & \\
\hline 4. disagree & 396 & 134 & 173 & 357 & 331 & 199 & 347 & 183 & \\
\hline 5. fully disagree & 112 & 32 & 46 & 98 & 104 & 40 & 94 & 50 & \\
\hline
\end{tabular}




\begin{tabular}{|l|c|c|c|c|c|c|c|c|c|}
\hline Total: & 861 & 280 & 392 & 749 & 740 & 401 & 705 & 436 & \\
\hline chi-square & 1.5518 & & 6.5653 & & 9.9070 & & 9.3032 & & \\
p-value & 0.8174 & & 0.1607 & & 0.1409 & & 0.0540 & & \\
\hline
\end{tabular}

Explanation: HE - respondents with higher education, $\mathrm{OE}$ - respondents with other education, Micro - microenterprises, OEn - other enterprises, 10+ - enterprises that operate for over 10 years, 10- enterprises that operate for less than 10 years.

H1 was confirmed. We found that only $9.55 \%$ of entrepreneurs rated the applied forms of state financial support as suitably adjusted. Our research has shown that there are no statistically significant differences between the designated social groups (men and women, entrepreneurs with higher education and others, and micro-enterprises and other enterprises, enterprises that operate in the market for over 10 years and others). A statistically significant difference was found when comparing the affirmative replies of entrepreneurs with higher education and entrepreneurs with other types of education $(\mathrm{p}$-value $=0.0424)$. These entrepreneurs optimistically evaluate forms of state financial support. One of the reasons could be that the higher level of education allows them to better orientate in the system of support, or to get this form of support easier.

Research has shown that the assessment of state financial support by the SMEs is significantly negative, which was confirmed by the $59.07 \%$ of entrepreneurs. Based on these data we can state that the points of views of Czech SMEs and the government representatives vary considerably.

$31.38 \%$ of respondents do not have a stance to the problem. In this context it would be appropriate to examine the reasons for this attitude, because if it was principally determined by the disinterest in state financial support for business development and belief in own financial possibilities, it would be a very positive signal for the future.

In Table 2 we present the level of intensity of the perceived support of surrounding from the side of the entrepreneurs in the Czech Republic. 
Tab. 2 - The perceived support of surrounding from the side of the entrepreneurs. Source: own source

\begin{tabular}{|l|c|c|c|c|c|c|c|c|c|}
\hline \multicolumn{8}{|c|}{ I feel the support of my surroundings for my entrepreneurial activities. } \\
\hline & Men & $\begin{array}{c}\text { Wom- } \\
\text { en }\end{array}$ & HE & OE & Micro & OEn & $10+$ & 10 - & $\begin{array}{c}\text { P-value } \\
\text { Z-score }\end{array}$ \\
\hline 1. strongly agree & 144 & 45 & 76 & 113 & 128 & 61 & 113 & 76 & \\
\hline $\begin{array}{l}\text { 2. agree } \\
\text { share in \% (1+2) } \\
\text { share in \% } \\
\text { total: 64.07 }\end{array}$ & 391 & 151 & 196 & 346 & 346 & 196 & 320 & 222 & 0.0173 \\
\hline $\begin{array}{l}\text { 3. no stance to } \\
\text { the problem }\end{array}$ & 222 & 70.00 & 69.39 & 61.28 & 64.05 & 64.09 & 61.42 & 68.35 & $\begin{array}{c}0.0067 \\
0.9920\end{array}$ \\
\hline 4. disagree & 86 & 22 & 35 & 73 & 75 & 33 & 78 & 30 & \\
\hline $\begin{array}{l}\text { 5. fully } \\
\text { disagree }\end{array}$ & 18 & 5 & 3 & 20 & 15 & 8 & 13 & 10 & \\
\hline $\begin{array}{l}\text { Total: } \\
\text { chi-square } \\
\text { p-value }\end{array}$ & 6.9365 & 280 & 392 & 749 & 740 & 401 & 705 & 436 & \\
\hline
\end{tabular}

Explanation: HE - respondents with higher education, OE - respondents with other education, Micro - microenterprises, OEn - other enterprises, 10+ - enterprises that operate for over 10 years, 10- enterprises that operate for less than 10 years.

H2 was partially confirmed. We found out that $64.07 \%$ of Czech entrepreneurs feel the support of their surroundings for entrepreneurship. At the same time, we found that there are no statistically significant differences in the overall responses between the designated social groups (except education). Statistically significant differences were detected in the affirmative replies within defined social groups. Women felt more intensive support of their surroundings than men ( $p$-value $=0.0173)$, entrepreneurs with higher education $(p$-value $=0.0067)$ and older enterprises $(p$-value $=0.0178)$ felt higher support of their surroundings in comparison with the entrepreneurs with lower levels of education and "younger companies".

Table 3 presents the results of the evaluation of access to external sources of financing by the Czech SMEs.

The first part of $\mathrm{H} 3$ was confirmed. We found that $45.49 \%$ of entrepreneurs think that SMEs have difficulties in access to external sources of financing (financial markets, banks, loans from the State). The second part of $\mathrm{H} 3$ was partially confirmed. We found that there were no statistically significant differences in the overall responses between the designated social groups (with the exception of the comparison of microenterprises and other enterprises, where we calculated the p-value 4E-05).

The calculated p-value (0.0949), which is near the criterion value of 0.05 indicates that smaller companies perceive the limitations in access to external sources of financing for intensively. This finding is compatible with the findings in the presented sources (Pervan and Kuvek, 2013, Canton, Grilo, Monteagudo, and Zwan, 2013; Fetisovová et al., 2012; Májková, 2012; MPO, 2014). Our research does not confirm the point of view of the Ministry of Industry and Trade, which states in its report that, in general it can be said that Czech SMEs did not have substantial problems with the access to bank financing in 2013. (MPO, 2014) 
Tab. 3 - The evaluation of access of SMEs to external sources of financing. Source: own source

\begin{tabular}{|l|c|c|c|c|c|c|c|c|c|}
\hline \multicolumn{7}{|c|}{ SMEs have restricted access to external sources of financing. } \\
\hline & Men & $\begin{array}{c}\text { Wom- } \\
\text { en }\end{array}$ & HE & OE & Micro & OEn & $10+$ & 10 - & $\begin{array}{c}\text { P-value } \\
\text { Z-score }\end{array}$ \\
\hline 1. strongly agree & 39 & 13 & 15 & 37 & 36 & 16 & 35 & 17 & \\
\hline $\begin{array}{l}\text { 2. agree } \\
\text { share in \% (1+2) } \\
\text { share in \% } \\
\text { total: } 45.49\end{array}$ & 348 & 119 & 151 & 316 & 314 & 153 & 276 & 191 & 0.5222 \\
\hline $\begin{array}{l}\text { 3. no stance to } \\
\text { the problem }\end{array}$ & 313 & 97.14 & 42.35 & 47.13 & 47.30 & 42.14 & 44.11 & 47.71 & 0.1236 \\
\hline 4. disagree & 142 & 46 & 79 & 109 & 92 & 96 & 121 & 67 & \\
\hline $\begin{array}{l}\text { 5. fully } \\
\text { disagree }\end{array}$ & 19 & 3 & 6 & 16 & 14 & 8 & 17 & 5 & \\
\hline Total: & 861 & 280 & 392 & 749 & 740 & 401 & 705 & 436 & \\
\hline $\begin{array}{l}\text { chi-square } \\
\text { p-value }\end{array}$ & 1.7007 & & 6.9372 & & 25.5203 & & 4.8822 & & \\
\hline
\end{tabular}

Explanation: HE - respondents with higher education, OE - respondents with other education, Micro - microenterprises, OEn - other enterprises, 10+ - enterprises that operate for over 10 years, 10- enterprises that operate for less than 10 years.

Table 4 presents the survey results in the intensity of the influence of the market risk in the business area of Czech SMEs.

Tab. 4 - The intensity of the influence of the market risk in the SMEs segment. Source: own source

\begin{tabular}{|l|c|c|c|c|c|c|c|c|c|}
\hline \multicolumn{7}{|c|}{ SMEs feel the intensive influence of market risk (lack of orders) } \\
\hline & Men & $\begin{array}{c}\text { Wom- } \\
\text { en }\end{array}$ & HE & OE & Micro & OEn & $10+$ & 10 - & $\begin{array}{c}\text { p-value } \\
\text { Z-score }\end{array}$ \\
\hline 1. strongly agree & 60 & 16 & 27 & 49 & 47 & 29 & 55 & 21 & \\
\hline $\begin{array}{l}\text { 2. agree } \\
\text { share in \% (1+2) } \\
\text { share in \% } \\
\text { total: } 51.18\end{array}$ & 51.33 & 50.71 & 48.98 & 52.34 & 52.57 & 48.63 & 52.62 & 48.85 & 0.2801 \\
\hline $\begin{array}{l}\text { 3. no stance to } \\
\text { the problem }\end{array}$ & 215 & 83 & 104 & 194 & 206 & 92 & 171 & 127 & \\
\hline 4. disagree & 191 & 46 & 92 & 145 & 131 & 106 & 149 & 88 & \\
\hline $\begin{array}{l}\text { 5. fully } \\
\text { disagree }\end{array}$ & 13 & 9 & 4 & 18 & 14 & 8 & 14 & 8 & \\
\hline Total: & 861 & 280 & 392 & 749 & 740 & 401 & 705 & 436 & \\
\hline $\begin{array}{l}\text { chi-square } \\
\text { p-value }\end{array}$ & 8.8362 & & 5.5223 & & 13.6052 & & 6.2395 & & \\
\hline
\end{tabular}

Explanation: HE - respondents with higher education, OE - respondents with other education, Micro - microenterprises, OEn - other enterprises, 10+ - enterprises that operate for over 10 years, 10- enterprises that operate for less than 10 years. 
The first part of $\mathrm{H} 4$ was confirmed. We found that $51.18 \%$ of entrepreneurs in the segment of SMEs experience intensive influence of market risk. The second part of the H4 was not confirmed. While we found that there were statistically significant differences in the overall responses between the designated social groups (men and women, and micro enterprises and other enterprises), but in the structure of the positive responses we have not found any statistically significant differences between the social groups.

The similar situation is in Slovakia too. The most important business risk which was perceived by $51.30 \%$ entrepreneurs (average value) in the Slovak Republic was the market risk. It was found out that compared with pre-crisis period, the performance of SMEs in Slovakia have decreased by at least 15\%. (Belás, Bilan, Ključnikov, Vincúrová and Macháček, 2015).

\section{CONCLUSION}

Quality business environment creates favorable conditions for the development of SMEs, which represent an important part of the national economic system. Not only economic criteria, but also social, educational, cultural and other factors are playing an important role in this process.

Our research shows that the assessment of state financial support by Czech entrepreneurs is significantly different from the official documents of the Czech government.

Entrepreneurs in our survey indicated a relatively high level of support of their entrepreneurial activities by the immediate surrounding. The perception of entrepreneurs in society is still quite negative and it is probable that it will not be able to change this picture in the short term.

Czech entrepreneurs indicated that they felt restricted access to external financial resources and intensive influence of market risk, which together creates challenging business conditions.

An important finding is that entrepreneurs with higher education are better prepared for business, because in comparison with other entrepreneurs they presented a better stance to defined quality parameters of the business environment. These entrepreneurs optimistically evaluated forms of state financial support, better evaluated the surrounding relationship to their business activities, and showed more optimism while evaluating SMEs access to external financial resources and less feared the market risks. The research results indicate that the business environment is more challenging for microenterprises, which in comparison with SMEs showed a larger dose of pessimism in all evaluated areas.

Based on the evaluation of the results of our research we can conclude that there are barriers in the field of formation of the business environment in the Czech Republic. We think that the gradual establishment of better environment for the development of SMEs should be an important field of national economic activity.

\section{Acknowledgement}

This paper was created at the Tomas Bata University in Zlin and was supported by Project IGA/FaME/2015/022: The influence of socio-demographic factors on the entrepreneurial orientation of SMEs' entrepreneurs. 


\section{References}

1. Altman, E. I., Sabato, G., \& Wilson, N. (2010). The Value of Non-Financial Information in SME Credit Risk Management. The Journal of Credit Risk, 95: 95-127. doi:10.2139/ ssrn.1320612

2. Belás, J., Bilan, Y., Ključnikov, A., Vincúrová, Z., \& Macháček, J. (2015). Actual problems of business risk in segment SME. Case study from Slovakia. International Journal of Entrepreneurial Knowledge, 3(1), 46-56. DOI: 10.1515/ijek-2015-0010.

3. Belás, J., Macháček, J., Bartoš, P., Hlawiczka, R., \& Hudáková, M. (2014). Business risks and the level of entrepreneurial optimism of SME in the Czech and Slovak Republic. Journal of competitiveness, 6(2), 30-41. DOI: 10.7441/joc.2014.02.03.

4. Canton, E., Grilo, I., Monteagudo, J., \& Zwan, P.V.D. (2012). Perceived Credit Constraints in the European Union. Small Business Economics, 41(3), 710-715. DOI: 10.1007/s11187-012$9451-y$.

5. Diaz-Garcia, M. C., \& Jimenez-Moreno, J. (2009), Entrepreneurial intention: the role of gender. International Entrepreneurship Management Journal, 6(3), 261-283. DOI: 10.1007/s11365008-0103-2.

6. Goktan, A. B., \& Gupta, V. K. (2013). Sex, gender, and individual entrepreneurial orientation: evidence from four countries. International Entrepreneurship and Management Journal, 11(1), 95-112. DOI: 10.1007/s11365-013-0278-z.

7. Kato, M., Okamuro, H., \& Honjo, Y. (2015). Does founder human capital matter for innovation? Evidence from Japanese start-ups. Journal of Small Business Management, 53(1), 114-128. DOI: 10.1111/jsbm.12094.

8. Kundin, A., \& Erecgovac, R. (2011). Credit Rationing in Financial Distress: Croatia's SMEs Finance Approach. International Journal of Law and Management, 53(1), 62-84. DOI: http:// dx.doi.org/10.1108/17542431111111890.

9. Langowitz, N., \& Minniti, M. (2007). Entrepreneurial propensity of women. Entrepreneurship Theory and Practice, 31(3), 341-364. DOI: 10.1111/j.1540-6520.2007.00177.x.

10. Májková, M. (2012). Moそ̌nosti financovania malých a stredných podnikov v SR. Brno: Tribun.

11. Millian, J. M., Congregado, E., Roman, C., Van Praag, M., \& Van Stel, A. (2014). The value of an educated population for an individual's entrepreneurship success. Journal of Business Venturing, 29, 312-632. DOI 10.1016/j.jbusvent.2013.09.003.

12. MPO. (2014). Zpráva o vývoji malého a strédního podnikáni a jeho podpoře v roce 2013. Praha: Ministerstvo průmyslu a obchodu ČR.

13. Ozturk, B., \& Mrkaic, M. (2014). Access to Finance by SMEs in the Euro Area_What Helps or Hampers. IMF Working Paper, European Department.

14. Pavelková, D. et al. (2009). Klastry a jejich vliv na výkonnost firem. Praha: Grada.

15. Pervan, I., \& Kuvek, T. (2013). The relevant Importance of Financial Ratios and NonFinancial variables in Predicting of Insolvency. Croatian Operational research review, 4, 187-197. 
16. Rauch, A., \& Rijsdijk, S. A. (2013). The effects of general and specific human capital on long-term growth and failure of newly founded businesses. Entrepreneurship Theory and Practice, 37(4), 923-941. DOI: 10.1111/j.1540-6520.2011.00487.x.

17. Runyan, C. R., Huddleston, P., \& Swinney, J. (2006). Entrepreneurial orientation and social capital as small firm strategies: a case study of gender differences from resources-based view. Entrepreneurship Management, 2(4), 455-477. doi:10.1007/s11365-006-0010-3

18. Wang, W. (2012). How the small and medium-sized enterprises' owners' credit features affect the enterprises' credit default behaviour? E3 Journal of Business Management and Economics, 3(2), 090-095.

19. Social Science Statistics. (2015). Retrieved September 20, 2015, from http://www. socscistatistics.com/tests.

20. Social Science Statistics. (2015). Z Test Calculator for 2 Population Proportions. Retrieved September 20, 2015, from http://www.socscistatistics.com/tests/ztest/Default2.aspx.

\section{Contact information}

Ing. Aleksandr Ključnikov, PbD.

Business School Ostrava plc

Michálkovická 1810/181, 71000 Ostrava

E-mail: aleksadr.kljucnikov@vsp.cz.

prof. Ing. Jaroslav Belás, PhD.

Department of Enterprise Economics

Faculty of Management and Economics

Tomas Bata University in Zlin

Mostni 5139, 76001 Zlin

E-mail:belas111@gmail.com

Ing. Ludmila Kozubiková, PhD.

Department of Enterprise Economics

Faculty of Management and Economics

Tomas Bata University in Zlin

Mostni 5139, 76001 Zlin

E-mail:kozubikova@fame.utb.cz.

Bc. Pavla Paseková

Department of Enterprise Economics

Faculty of Management and Economics

Tomas Bata University in Zlin

Mostni 5139, 76001 Zlin

E-mail:p.pasekova@fame.utb.cz. 